\title{
Performance indicators of the electric grid company
}

\author{
Inga Skvortsova $^{1, *}$, Elizaveta Grebenkina ${ }^{2}$ and Tamara Narezhnaya $^{3}$ \\ ${ }^{1}$ Peter the Great St. Petersburg Polytechnic University, 29, Polytechnicheskaya str., 195251, Russia \\ ${ }^{2}$ IDGS of the North-West, 3A, Constitution Square, 195251, St. Petersburg Russia \\ ${ }^{3}$ Moscow State University of Civil Engineering, Yaroslavskoe sh., 26, 129337, Moscow, Russia
}

\begin{abstract}
Network economy is one of the main infrastructures that are included in Russian fuel and energy complex. It covers almost all country and people, including industrial and commercial customers, need it. The main task of every successful company is analysis and assessment of performance indicators and looking for ways for their raising. Company's performance depends on quality and reliability of power supply to customers and right company's management. So, there is a reason to investigate and analyze these indicators. The goal of the article is definition of performance indicators of electric grid company on the example of IDGC of North-West, PJSC. There are some tasks to achieve the goal: analysis of Russian electric grid complex; definition of performance indicators of electric grid company; assessment of performance indicators of electric grid company.
\end{abstract}

\section{The analysis of Russian electric grid complex}

The electric grid complex of Russian Federations is a complex organization and technical system. Management of electric grid complex based on the main principles of management.

Thereby, management of electric grid complex is a set of principles, methods and functions of management, the purpose of which is to increase efficiency of company and to raise profit.

So, electric grid company has an object and a subject.

The object of management is organization, the point of which is transmission and distribution electric energy. The subjects are individuals and legal entities, from whom powerful influence emanates.

Transmission and distribution of electric energy in Russia are provided by PJSC Rosseti. The PJSC Rosseti is an operator of main and distribution energy grids, which are regulated by the government. Also, there are some private companies (for example, JSC BESK, PJSC SUENKO e.t.p.). [1]

The structure of PJSC Rosseti is presented on the figure 1.

\footnotetext{
* Corresponding author: ingaskvor@list.ru
} 


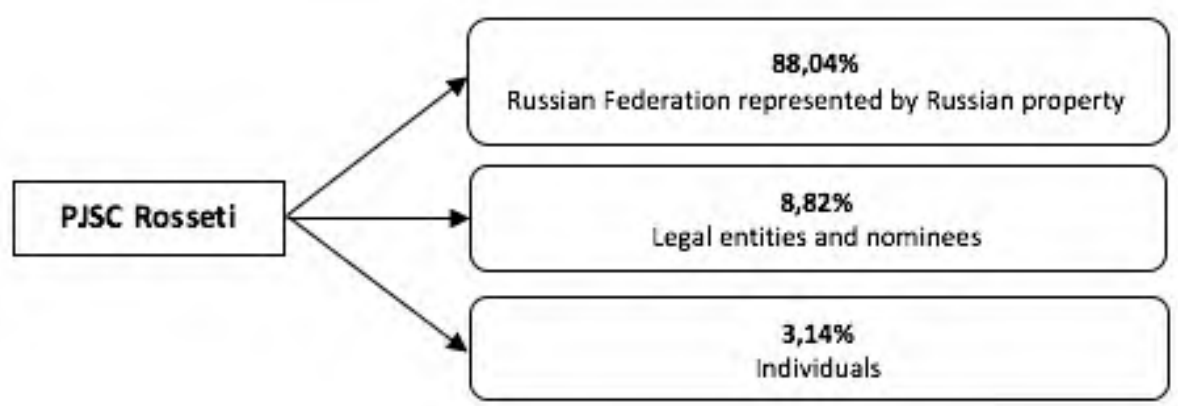

Fig. 1. The structure of PJSC Rosseti.

$75 \%$ of Russian electric energy is transmitted through grids of PJSC Rosseti, $90 \%$ of main and $70 \%$ of distribution energy grids are operated by PJSC Rosseti.

According to the Strategy of development distributional electric complex of Russian Federation the structure of Russian electric grid complex can be built like this:

- Federal Grid Company of United Energy System (FGC UES);

- Interregional Distribution Grid Companies (IDGC);

- Territorial Grid Organizations (TGO).

About $90 \%$ of transmission lines with voltage $220-750 \mathrm{kV}$ are operated by FGC UES, other $10 \%$ by independent organizations. Lines with voltage $0,4-110 \mathrm{kV}$ ( $70 \%$ of market) operated by Interregional Distribution Grid Companies (14 pieces in Russia). Lines 0,4$10 \mathrm{kV}(30 \%$ of market) operated by territorial grid organizations (about 3000 pieces in Russia). [2]

PJSC Rosseti operates in 80 regions of Russia and plans to expand the geography of its presence for operation throughout Russian Federation. The number of entities with the presence of PJSC Rosseti presents in the table 1.

Table 1. The number of entities with the presence of PJSC Rosseti [3].

\begin{tabular}{|l|c|c|}
\hline $\begin{array}{c}\text { The name of federal } \\
\text { district (FD) }\end{array}$ & $\begin{array}{c}\text { The number of entities } \\
\text { with the presence of } \\
\text { PJSC Rosseti }\end{array}$ & $\begin{array}{c}\text { The number of entities without } \\
\text { the presence of PJSC Rosseti }\end{array}$ \\
\hline Central FD & 18 & 0 \\
\hline North-West FD & 11 & 0 \\
\hline Volga FD & 14 & 0 \\
\hline Southern FD & 7 & 1 \\
\hline North Caucasian FD & 7 & 0 \\
\hline Ural FD & 6 & 0 \\
\hline Siberian FD & 10 & 0 \\
\hline Far Eastern FD & 7 & 4 \\
\hline
\end{tabular}

In 2018 the length of transmission lines of PJSC Rosseti was 2,35 million kilometers, the number of substations - 507 thousand, the power of substations - 792GVA. The dynamic of development presents on pictures 2, 3, 4 in the form of diagrams. [4] 


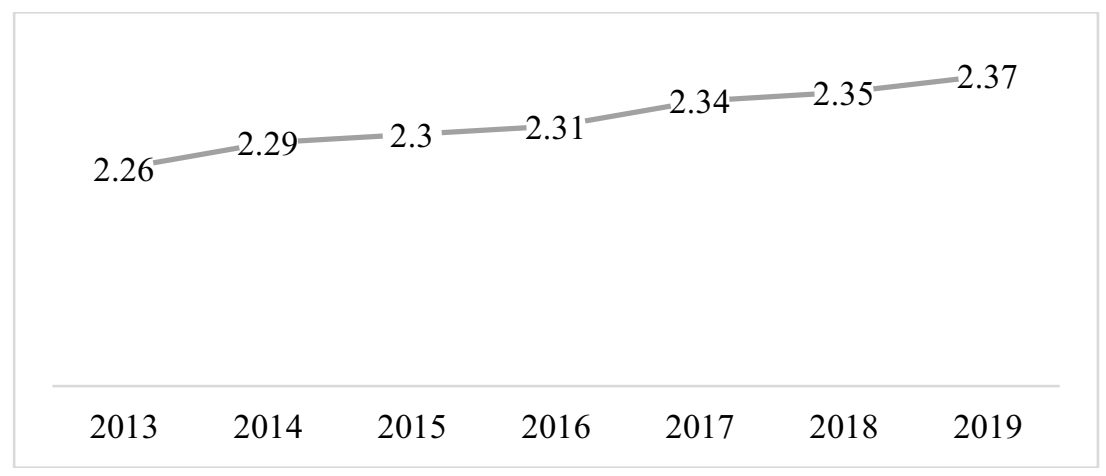

Fig. 4. The number of substations of PJSC Rosseti (2016-2018), thousand.

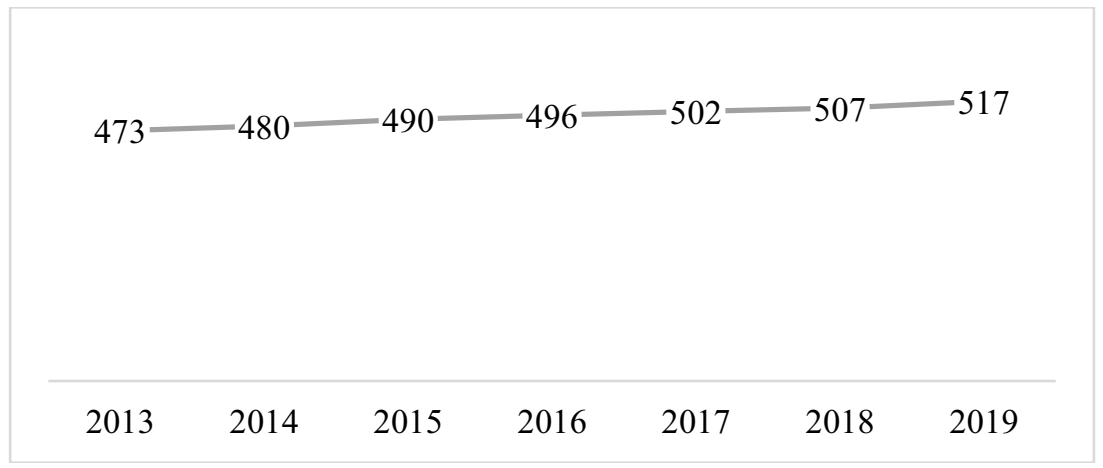

Fig. 3. The number of substations of PJSC Rosseti (2016-2018), thousand.

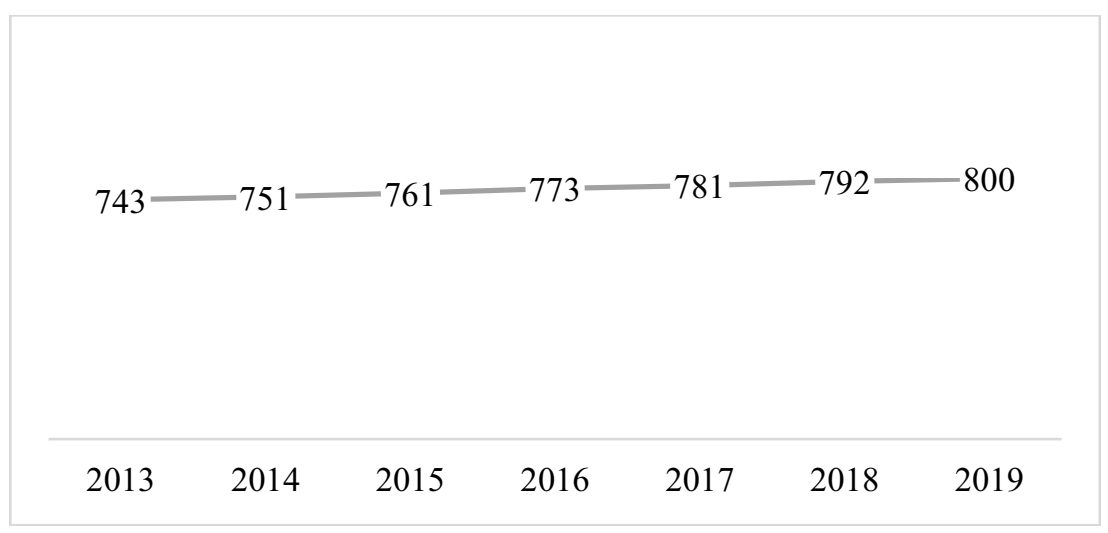

Fig. 4. The power of substations of PJSC Rosseti (2016-2018), GVA.

However, the state of Russian electric grid assets is much worse than in another countries. The lack of necessary investments in the electric grid complex in the past 20 years has led to significand physical and technological obsolescence of electric grids. In 2016 the share of electric grids which has worked out its service life was $50 \%$, the share of electric grids which worked out its service life twice $-75 \%$. The general wearout of electric grids was $70 \%$. The wearout of main electrical grids was $50 \%$, transmission lines $-70 \%$. Main objects were commissioned in 1970-1980s. In another countries the indicator of wearout is $27-44 \%$. [5]

Modern equipment, that provides reliability and reduction in operation costs, isn't widely used now. 


\section{Performance indicators of electric grid company}

The efficiency of electric grid company is a level of achievement of the company's goals, its financial results.

There are 7 ways of assessment of company's efficiency: marketing analysis, the analysis of the effectiveness of the introduction of new technologies, the analysis of the effectiveness of staff management, the analysis of productive fixed capital assets, the analysis of reliability of electric supply and customer satisfaction, financial analysis.

Capital productivity, capital intensity, fund profitability and capital-labor ratio will be appreciated for analysis of efficiency of productive fixed capital assets.

The reliability of electric supply and customer satisfaction can show the level of reliable of electric grid company.

The reliability is an object's ability to maintain its properties over time and within established limits and perform a number of required functions in various conditions of use, maintenance, storage and transportation.

So, reliability is an inadmissibility of layers in the work of one or more objects.

The reliability of electric supply is an ability of electric grids to provide customers with electricity in required volume and quality.

According to the Federal low about electric power industry №35, subjects of electric power industry which provide customers electricity, are responsible for reliability of providing of electricity and its quality. [6]

The customer satisfaction is a compliance with the revivals of customers of the provided services.

The financial analysis is a process of information selection about financial condition and results of financial activity of company for assessment of current statement and organization of events for future development.

Financial indicators include solvency indicators (absolute ratio, current ratio), indicators of financial stability (autonomy ratio, equity ratio), business activity indicators (period of assets turnover, period of capital turnover, account receivable days, account payable days, period of inventory turnover), profitability indicators (sales margin, return on assets by profit from sales, return on assets by profit before tax, return on equity capital by profit from sales, return on equity capital by the net profit).

Marketing in power grid companies is needed, first of all, to determine the technical ability of the company to perform its services in full (to identify the presence of overloaded sections of the network and equipment of transformer substations) and the prospects for the development of the company, justification of tariffs for services. To do this, it is necessary: to assess the volume and characteristics of the electricity (capacity) market in the served area, to identify potential consumers (by voltage class, by assignment to a consumer group, by the criterion of reliability, by participation in the peak load, solvency, etc.), to assess the competitive environment (the possibility of building their own energy sources or connecting to other networks), justify tariffs for services for technological connection to the network and for the transmission of electricity, as well as, possibly, a system of discounts and surcharges (for reliability, for consumption of reactive power, for connecting to a "narrow place ", etc.). [7]

As for the analysis of personnel management, this is an equally important aspect in assessing the effectiveness of the company as a whole. In 1970-1990, the staff of the Department of Social Psychology of St. Petersburg State University proved the mutual influence of objective and subjective factors.

Thus, the labor, spiritual and social activity of workers depends on: 
- the balance of moral and material incentives for labor (it turned out that an orientation exclusively towards material incentives for labor does not lead to a significant increase in labor activity)

- the presence in the organization of an initiative group of people, putting forward goals, surrounding the interests and needs of employees, able to convincingly prove the need for their proposed innovations;

- the age of employees (young employees show great social activity, and middle-aged employees are distinguished by high labor activity). [8]

When assessing the effectiveness of personnel, the following are considered:

- volume of work performed;

- the complexity of the tasks;

- features of assigned functional duties;

- labor results.

As a methodology for assessing the work of personnel, you can take certification, testing (questioning), "Assessment Center", biography, game, observation, interview, performance management or target management.

If the company manages to properly organize the work of the personnel, the efficiency of the company will increase significantly.

Innovation activity is a complex of scientific, technological, organizational, financial and commercial measures aimed at the implementation of innovative projects, as well as at the creation of innovative infrastructure and its provision. [9]

Innovation activities include identifying enterprise problems, implementing the innovation process and organizing innovative activities.

The introduction of new technologies is due to the constant changes in the situation in the world, in the market, at the enterprise, as well as the need for the development of the enterprise and its improvement.

The global trend in the development of innovative technologies in the field of electrical distribution networks is the creation of a "smart" grid (Smart Grid)

Among the priority innovative technologies are:

- intelligent electricity metering systems and improving the quality of customer service;

- introduction of modern automation systems and network automation;

- development of integration of distributed generation, including renewable energy sources;

- digital substations (based on open standards IEC (IEC) 61850);

- technologies for reactive power compensation;

- electric vehicles and their charging infrastructure;

- network energy storage systems.[10]

In parallel, companies are developing developments aimed at maintaining the existing

level of functioning of the power grid infrastructure or improving production processes:

- protective coatings and polymer insulators;

- high voltage cables.

The following can be named as indicators of the company's investment performance:

- payback period of the investment project (PB);

- discounted investment payback period (DPB);

- average rate of return (ARR);

- net present value (NPV);

- internal rate of return (profitability) (IRR);

- modified internal rate of return (MIRR). 


\section{Assessment of performance indicators of electric grid company for example IDGC of North-West, PJSC}

Of all the aspects, the analysis of indicators of the efficiency of the use of fixed assets and the analysis of the reliability of power supply and customer satisfaction will be considered in more detail.

The results of calculating of productive fixed capital assets of IDGC of North-West, PJSC presets in the table 3.

Table 3. Productive fixed capital assets of IDGC of North-West, PJSC.

\begin{tabular}{|l|c|c|c|c|c|c|c|}
\hline $\begin{array}{c}\text { Name of } \\
\text { indicator }\end{array}$ & $\mathbf{2 0 1 3}$ & $\mathbf{2 0 1 4}$ & $\mathbf{2 0 1 5}$ & $\mathbf{2 0 1 6}$ & $\mathbf{2 0 1 7}$ & $\mathbf{2 0 1 8}$ & $\mathbf{2 0 1 9}$ \\
\hline $\begin{array}{l}\text { Capital } \\
\text { productivity }\end{array}$ & 1.0704 & 1.0621 & 0.9304 & 0.9942 & 1.0124 & 1.3236 & 0.9494 \\
\hline $\begin{array}{l}\text { Capital } \\
\text { intensity }\end{array}$ & 0.9342 & 0.9415 & 1.0749 & 1.0058 & 0.9877 & 0.7555 & 1.0533 \\
\hline $\begin{array}{l}\text { Fund } \\
\text { profitability }\end{array}$ & 0.0187 & 0.0127 & 0.0207 & 0.0175 & 0.0647 & 0.0231 & 0.0169 \\
\hline $\begin{array}{l}\text { Capital- } \\
\text { labor ratio }\end{array}$ & 2577.74 & 2744.45 & 2877.42 & 2902.93 & 2984.99 & 2955.13 & 3257.17 \\
\hline
\end{tabular}

According to the table, indicators of capital productivity and fund profitability are growing every year. Conversely, capital intensity is decreasing, it means that efficiency of using productive fixed capital assets and competitiveness of company are growing.

As for the capital-labor ratio, by 2017 it increased compared to 2016, which indicates an increase in labor productivity of production personnel, but in 2018 it slightly decreased, after which growth is observed again by 2019 .

Indicators of the system average interruptions frequency index, the system average interruption duration index and the electrical energy losses was chosen for assessment of reliability of IDGC of North-West, PJSC. The data was taken from official annual report of IDGC of North-West, PJSC and presented in the table 4.

Table 4. Indicators of reliability of IDGC of North-West, PJSC.

\begin{tabular}{|l|c|c|c|c|c|c|c|}
\hline \multicolumn{1}{|c|}{ Name of indicator } & $\mathbf{2 0 1 3}$ & $\mathbf{2 0 1 4}$ & $\mathbf{2 0 1 5}$ & $\mathbf{2 0 1 6}$ & $\mathbf{2 0 1 7}$ & $\mathbf{2 0 1 8}$ & $\mathbf{2 0 1 9}$ \\
\hline $\begin{array}{l}\text { The system average } \\
\text { interuptions frequency } \\
\text { index (SAIFI). number }\end{array}$ & & & 2.43 & 2.05 & 1.59 & 1.4 & 1.9 \\
\hline $\begin{array}{l}\text { The system average } \\
\text { interruption duration index } \\
\text { (SAIDI). hours }\end{array}$ & & & 8.17 & 6.59 & 4.18 & 2.37 & 4.23 \\
\hline Electrical energy losses. \% & 6.39 & 6.41 & 6.31 & 7.28 & 6.59 & 6.59 & 6.23 \\
\hline
\end{tabular}

According to the table 4, indicators are decreasing every year. It means that reliability is growing. The dynamic of indicator's changes are presented on pictures 5, 6 and 7 


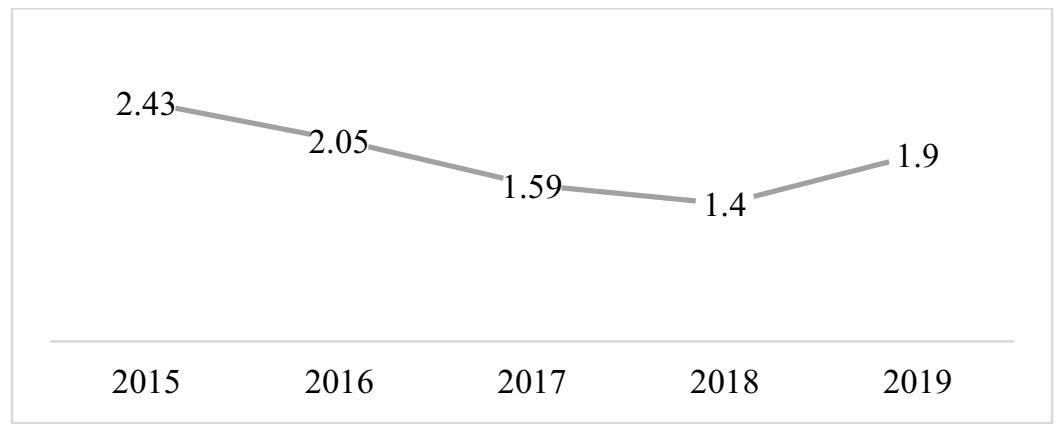

Fig. 5. Dynamic of changes of SAIFI.

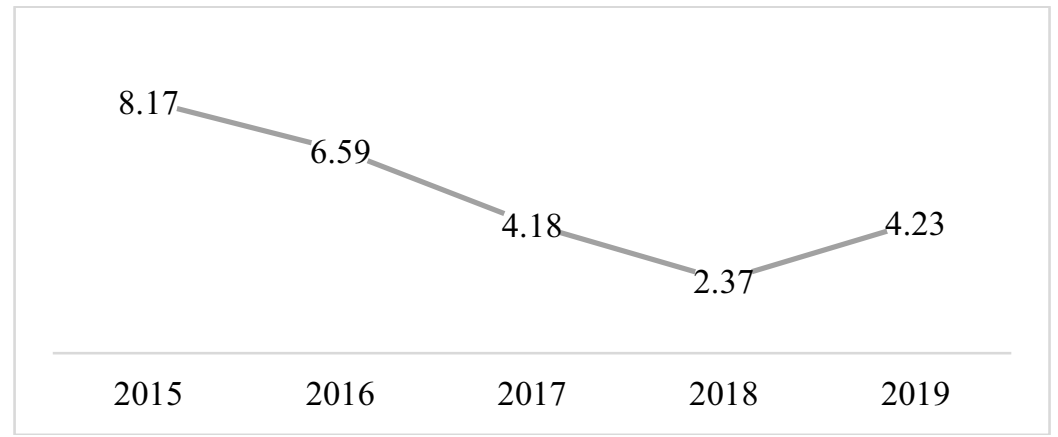

Fig. 6. Dynamic of changes of SAIFI.

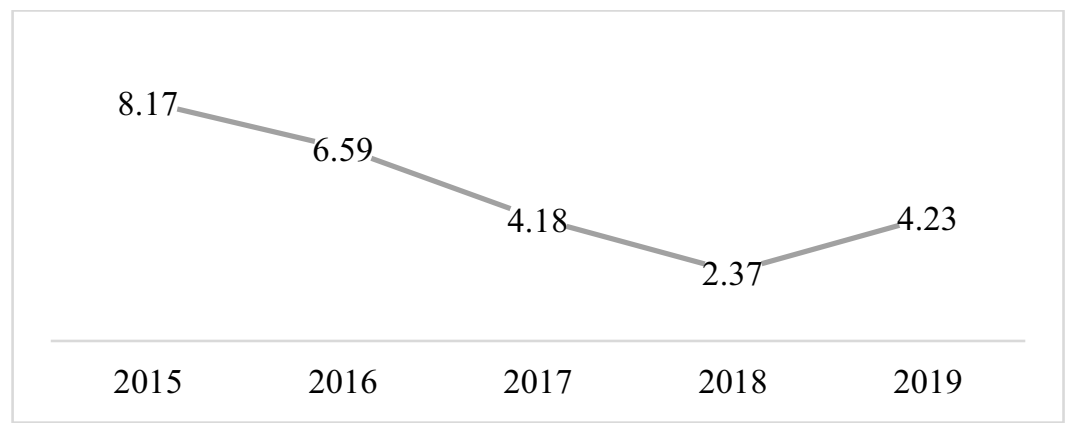

Fig. 7. Dynamic of changes of electricity losses.

\section{Results}

Results of the dynamic are related to the introduction of new technologies which allow to contract time and number of customer's outages. For example, new unmanned aerial vehicles with photography for monitoring of electric grids were commissioned in 2018. It allowed to contract operating costs, to reduce time for searching of damages, to raise safety of staff and to reduce time of customer's disconnection. Also, there were set up technologies as:

- DVRs for fixation of operational switching, briefing, carrying out work on objects that are raising the quality of work and safety of staff;

- reclosers and short circuit indicators in electric grids $6-10 \mathrm{kV}$ that give the ability localize damaged areas quickly and to contract number and time of disconnections in cases of customer's accidents; 
- smart metering devices with automated data collection and transmission and software packages for it that allow to reduce operating costs and electricity losses ant to increase grid's observability.

In addition, the level of electricity losses in greed was reduced by $10 \%$ since 2016 .

\section{References}

1. Annual report of PJSC Rosseti for 2018, https://mrsksevzap18.downstream.ru/?/ru

2. Order of the Government of the Russian Federation of 03.04.2013 N 511-p, http://www.consultant.ru/document/cons_doc_LAW_144676/

3. Order of the Government of the Russian Federation of 13.11.2009 N 1715-p "On the Energy Strategy of Russia for the period up to 2030", http://www.consultant.ru/document/cons_doc_LAW_94054/

4. Federal Law of March 26, 2003 N 35-FZ "On the Electric Power Industry", http://www.consultant.ru/document/cons_doc_LAW_41502/

5. N. Lubimova, Economics and management in energy: textbook for masters (2017)

6. M. Gorelik, Fundamentals of the economics of telecommunications (communications) (2005)

7. The program of innovative development of PJSC Rosseti for the period 2016-2020 with a perspective until 2025, https://www.rosseti.ru/investment/policy_innovation_development/doc/innovation_pr ogram.pdf 